\title{
Forest biodiversity and production potential of post-mining landscape: opting for afforestation or leaving it to spontaneous development?
}

\author{
Zdeněk Vacek*, Jan Cukor, Stanislav Vacek, Vilém Podrázský, Rostislav Linda, Jakub Kovařík \\ Czech University of Life Sciences Prague, Faculty of Forestry and Wood Sciences, Kamýcká 129, CZ - 16521 Prague 6 - Suchdol, \\ Czech Republic
}

\begin{abstract}
Land reclamation of post-mining sites strongly influences not only diversity and biomass of frequently studied ground vegetation, but also diversity of forest ecosystem. In most cases, spoil heaps are afforested after coal mining, but some reclaimed sites are left to spontaneous development, such as our study locality - surroundings of the Sokolov town, Czech Republic. Structure, species diversity and production potential were studied on three heap sites, artificially afforested by pedunculate oak (Quercus robur L.), black alder (Alnus glutinosa [L.] Gaertn) and silver birch (Betula pendula Roth) stands, and compared with three permanent research plots (PRP) left to natural succession processes with prevailing European aspen (Populus tremula L.), goat willow (Salix caprea L.) and also with silver birch. The timber production increased from the willow stand $\left(28 \mathrm{~m}^{3} \mathrm{ha}^{-1}\right)$ to birch ones $\left(97 \mathrm{~m}^{3} \mathrm{ha}^{-1}\right.$, all 45 years old). The mean stand volumes were significantly higher on afforested PRPs $\left(74 \mathrm{~m}^{3} \mathrm{ha}^{-1}\right)$ than on succession PRPs $\left(51 \mathrm{~m}^{3} \mathrm{ha}^{-1}\right)$, just as tree diameters. However, in terms of production quality, occurrence of breaks was significantly higher on afforested PRPs (15\%) compared to succession PRPs (7\%), while the opposite situation was observed in the stem quality. Horizontal structure of trees was regular on afforested PRPs, while spatial pattern on succession PRPs was aggregated. The highest differences in favor of succession PRPs was found in species richness and total stand diversity. These results imply a need for combined approaches in post-mining landscape management to support economic benefit and especially ecological value.
\end{abstract}

Key words: natural succession; forestry reclamation; ecological value; Antonín-Sokolov spoil heap; Czech Republic

Editor: Bohdan Konôpka

\section{Introduction}

The environment is being increasingly influenced by human activity that has, so far, significantly transformed more than a half of the Earth's surface (WWF 2016). On the entire planet Earth, forests, pastures, wetlands and other habitats are being transformed into an agricultural and urbanized landscape. The resulting loss of habitats is a serious driving force leading to a significant reduction in biodiversity (Tittensor et al. 2014; Lanz et al. 2018). Soil conversion also affects watercourses and the biogeochemical cycle of carbon, nitrogen and phosphorus and other important elements (Erisman et al. 2013). While individual cases of surface change occur locally, combined results have implications for Earth processes on a global scale (Brandi 2015).

The main reason for the change in landscape utilization in previous centuries was agricultural management (Ellis \& Ramankutty 2008; Feurdean et al. 2017;
Ustaoglu \& Williams 2017). One of increasingly discussed changes is the transformation of the landscape by mining minerals (Hildon 2002; Hendrichová \& Kabrna 2016). Mining activities influence vast areas, for example in Germany, brown-coal mining affected approximately $1550 \mathrm{~km}^{2}$ (Katzur \& Haubold-Rosar 1996); in the Czech Republic, approximately $400-420 \mathrm{~km}^{2}$ of land was transformed (Kupka \& Dimitrovský 2011).

In the Czech Republic, the area around the town of Sokolov represent such a large devastated land. In this area, there are about 9,250 hectares of land on which mining activities have already ended, or are still under way or are planned in the future (Kubát 2008). The total area of the Sokolov lignite basin is $219 \mathrm{~km}^{2}$ (Sklenička \& Charvátová 2003). The lives of people in the landscape, degraded in space and time by surface coal mining, are inextricably linked to the existence of greenery, water and air (Štýs 2001; Kubát 2008; Kupka \& Dimitrovský 2011). Recovery of these natural phenomena is a very complex 
and costly issue (Simon et al. 2005). Changes in the landscape structure caused by surface coal mining are crucial; mining is one of humanity's historical activities that create irreversible changes in the landscape (Slonecker \& Benger 2001; Hendrichová \& Kabrna 2016).

The long-term goal of restoration of the territory devastated by surface coal mining should be gradual creation of a mosaic-like landscape, which would meet various requirements, such as: production (forestry and agricultural reclamation), social (tourism) and non-productive, i.e. aesthetic, soil-protective and other requirements (Buček \& Lacina 2001; Hendrichová \& Kabrna 2016). Among the most important elements of a harmonious cultural landscape are forest ecosystems, representing potential climax communities with specific biodiversity in the Central European landscape (Prach 1995).

The forestry reclamation in the conditions of anthropogenically generated relief by mining in the Antonín forestry arboretum is to be considered, on the one hand, as a "controlled succession", where the tree species were planted as the key species of target forest ecosystems. On the other hand, a part of the arboretum area was left to spontaneous succession (Dimitrovský et al. 2007, 2010). The distinguishing features of the ligneous components of ecosystems lie in the way they affect the physical space in which other species live, and their direct effects may last longer than the life of an organism (Hastings et al. 2007). Organisms that predominantly direct courses of artificial ecosystem life are entering similar stages of ecological succession (Prach et al. 2016). The reclaimed soil and nitrogen-poor substrates in temperate zones are covered by forest areas in a relatively short time if a seed bank of pioneer trees is available (Rebele \& Lehmann 2016).

Forestry reclamation should not only be aimed at arbitrary planting the land with any trees, as used to be the case in the past (Štýs 2001; Knoche 2005). It is desirable to create sustainable and ecologically stable forest ecosystems, especially with the use of suitable, target autochthonous or introduced tree species (Vacek et al. 2009; Kupka \& Dimitrovský 2011). The use of native plant species with mycorrhiza is an excellent ecological engineering which strives to initiate and accelerate the re-colonization and stabilization of soils and raw materials stored in the landscape (Graf \& Frei 2013; Sýkorová et al. 2016). In general, site-suitable tree species can be considered as physical ecosystem engineers because they favorably modify their habitat and stand environment (Paz-Kagan et al. 2016; Prausová et al. 2017), especially by their beneficial effects on the soil environment and microclimate, including air cleanliness (Sádlo \& Tichý 2002). They contribute to overall restoration or regeneration of severely degraded, damaged or completely new habitats (Prach et al. 2016).

The aim of this paper, representing the first results of the Antonín spoil heap afforestation, was to evaluate biodiversity and production (quantity and quality) of the forest ecosystem after 45 years of post-mining landscape. Two types of stands were compared, namely stands established by a managed succession - by afforestation with autochthonous deciduous trees compared - with spontaneous succession by trees with pioneering growth strategy. The secondary aim was to determine differences in structure and production among stands with the different dominant deciduous tree species.

\section{Material and methods}

\subsection{Study area}

The study was conducted in six forest stands in the Antonín-Sokolov Forest Arboretum in post-mining landscape of the Sokolov area, in the west part of the Czech Republic (Table 1, Fig. 1). According to Czech Hydrometeorological Institute Sokolov station (4 km SW from town Sokolov, $402 \mathrm{~m}$ a. s. 1.), the average annual temperature in study area is $7.3^{\circ} \mathrm{C}$. The highest altitude of the Antonín Arboretum is $444 \mathrm{~m}$ a. s. l., the elevation to the surrounding terrain is $48 \mathrm{~m}$ (Dimitrovský et al. 2007, 2010). Long-term annual precipitation ranges from 327 to $658 \mathrm{~mm}$, the average sum in the Sokolov station is $611 \mathrm{mmy}^{-1}$. The most precipitation falls in July $(78 \mathrm{~mm})$, and the least in March (34 mm). The growing season ranges between $220-227$ days. The study territory is characterized by warm dry summers and cool dry winters with a narrow annual temperature range (Cfb) according to Köppen climate classification (Köppen 1936).

The soils in Forest Arboretum are currently in the initial stages of development (Dimitrovský et al. 2016). Initial dynamics of ground vegetation shows the trend towards potential association of Querceto-Fagetum acidophilum and Querceto-Fagetum lapidosum acidophilum forest site type according to Viewegh et al. (2003), despite a significant proportion of ruderal species in the first period of spontaneous succession. In waterlogged areas, the vegetation development corresponds to the association Querceto-Abietum variohumidum acidophilum and Fraxineto-Alnetum alluviale (Glos 2016). Forest site type

Table 1. Summary of basic site and stand characteristics of permanent research plots $1-6$.

\begin{tabular}{|c|c|c|c|c|c|c|c|c|}
\hline PRP & Forest origin & Species $^{1}$ & $\begin{array}{c}\text { Altitude } \\
\text { [m] }\end{array}$ & Exposure & $\begin{array}{c}\text { Slope } \\
{\left[{ }^{0}\right]}\end{array}$ & $\begin{array}{c}\text { Herbal cover } \\
{[\%]}\end{array}$ & Forest type & GPS coordinates \\
\hline $1 \mathrm{~A}$ & Afforestation & QR, BP & 410 & SW & 7 & $6-25$ & Acidic Oak-Beech & $50^{\circ} 9^{\prime} 52^{\prime \prime} \mathrm{N} 12^{\circ} 37^{\prime} 16^{\prime \prime E}$ \\
\hline $2 \mathrm{~A}$ & Afforestation & $\mathrm{AG}, \mathrm{FE}$ & 415 & $\mathrm{~S}$ & 6 & $51-75$ & Acidic Oak-Beech & $50^{\circ} 9^{\prime} 47^{\prime \prime} \mathrm{N} 12^{\circ} 37^{\prime} 22^{\prime \prime E}$ \\
\hline $3 \mathrm{~A}$ & Afforestation & $\mathrm{BP}$ & 425 & S & 7 & $51-75$ & Acidic Oak-Beech & $50^{\circ} 9^{\prime} 51^{\prime \prime} \mathrm{N} 12^{\circ} 37^{\prime} 30^{\prime \prime E}$ \\
\hline $4 \mathrm{~S}$ & Succession & $\mathrm{BP}, \mathrm{SC}, \mathrm{AG}$ & 420 & S & 1 & $76-100$ & Acidic Oak-Beech & $50^{\circ} 9^{\prime} 49^{\prime \prime} \mathrm{N} 12^{\circ} 37^{\prime} 25^{\prime \prime} \mathrm{E}$ \\
\hline $5 S$ & Succession & $\mathrm{SC}, \mathrm{AG}, \mathrm{FE}$ & 415 & S & 6 & $76-100$ & Acidic Oak-Beech & $50^{\circ} 9^{\prime} 48^{\prime \prime} \mathrm{N} 12^{\circ} 37^{\prime} 24^{\prime \prime} \mathrm{E}$ \\
\hline $6 \mathrm{~S}$ & Succession & PT, BP, AG, SC, TC & 420 & S & 4 & $76-100$ & Acidic Oak-Beech & $50^{\circ} 9^{\prime} 50^{\prime \prime} \mathrm{N} 12^{\circ} 37^{\prime} 30^{\prime \prime} \mathrm{E}$ \\
\hline
\end{tabular}

Notes: ${ }^{1} \mathrm{QR}$ - Quercus robur, BP - Betula pendula, AG - Alnus glutinosa, FE - Fraxinus excelsior, SC - Salix caprea, PT - Populus tremula, TC - Tilia cordata. 


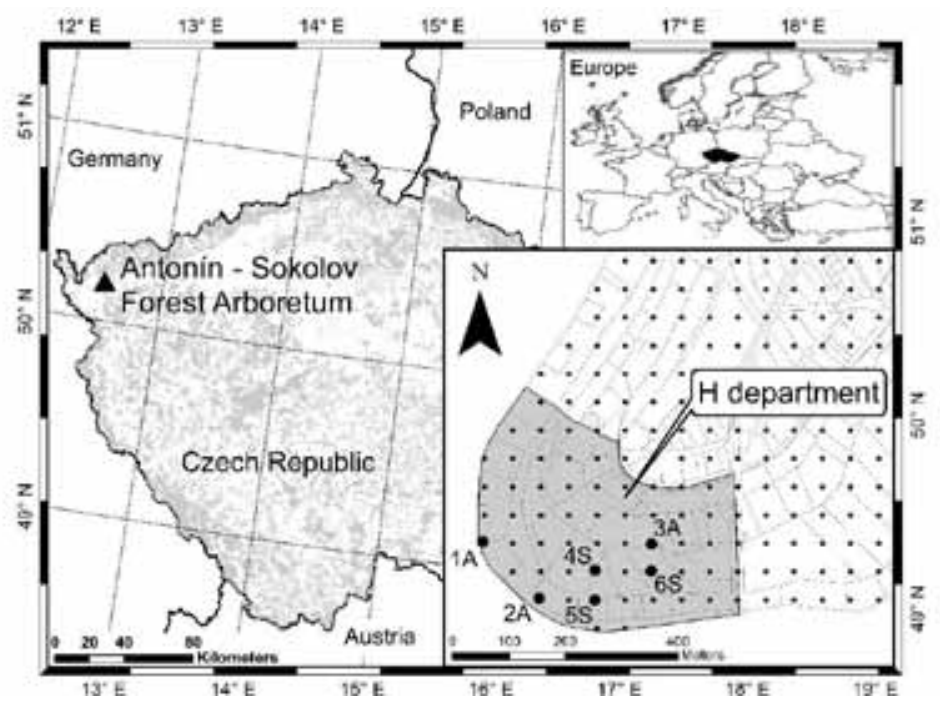

Fig. 1. Location of Antonín-Sokolov Forest Arboretum with plot network and study permanent research plots $(1 \mathrm{~A}-3 \mathrm{~A}, 4 \mathrm{~S}-6 \mathrm{~S})$ falling within $\mathrm{H}$ department highlighted by gray color.

of permanent research plots is in the forest management plan described like Acidic Oak-Beech.

Historically, the Antonín-Sokolov coal mine was in operation between 1881 and 1965 (until 1945 the mine was named Luipold), first as a deep, later as a surface coal mine. In the last 20 years (1945-1965) 22.5 million t of coal and 10.8 million $\mathrm{m}^{3}$ of overburden materials were mined (Jiskra 1997). After its closure in 1965, the coal mine was gradually filled up by overburden material from the coal mine Medard and by ash from a nearby power plant, so the surface of the spoil heap is structurally and texturally petrographically unordered. Most of the area consists of mild slopes interrupted by platforms providing anti-erosion measures. The dewatering of the spoil heap surface is made by open, unpaved ditches in the north to northwest direction. In some places, several smaller water areas and wetlands have emerged, which are currently in decline (Dimitrovský 2001). The study Antonín-Sokolov Forest Arboretum was established in 1969-1974 on the Antonín coal spoil heap (dump) close to the town of Sokolov. Technical operations, i.e. transporting and spreading the topsoil, were completed in 1971-1972, followed by forest reclamation. A wide assortment of 220 species, ecotypes and phenotypes of trees and shrubs and over than 30 introduced tree species were gradually planted on the study area of 165 ha, where a part of spoil heap was left to self-development to spontaneous succession. Resulting forest stands of Arboretum were left without silviculture intervention, and thinning was directed focused only to sublevel (Dimitrovský et al. 2007, 2010).

\subsection{Data collection}

The FieldMap technology (IFER-Monitoring and Mapping Solutions Ltd.) was used to establish six perma- nent research plots (PRPs) of $10 \times 15 \mathrm{~m}$ in size in 2017 . PRPs were randomly (RNG in MS excel) chosen from a plot network of $50 \times 50 \mathrm{~m}$ in measured department $\mathrm{H}$ (consisting of 55 PRPs), each representing different deciduous tree species (Table 1, Fig. 1). PRPs were network-based in the direction perpendicular to the slope or in the north-south direction on a plane terrain situated in one forest stand. Study three PRPs were established by managed afforestation (PRP 1A-3A) and three PRPs were left to spontaneous succession (PRP 4S-6S). Using the FieldMap system, the position and crown projections at a minimum of four directions perpendicular to each other were measured in the tree layer with diameter at breast height $(\mathrm{DBH})>4 \mathrm{~cm}$. In the tree layer, DBH was measured with a metal calliper (1 $\mathrm{mm}$ accuracy) and the total height and height to crown base with a Vertex laser hypsometer $(0.1 \mathrm{~m}$ accuracy). The methodology of tree measurement was based on the National Forest Inventory (ÚHÚL 2003). The IUFRO tree classification and the Schädelin tree classification (Schädelin 1931) was used for evaluation of coenotic position (dominant, intermediate, suppressed tree), vitality (lush growth, average, dying), stem quality (ductile straight, slightly curved, poor-quality curved stem) and crown quality (good large symmetric, average, defective small asymmetric crown). Tree damage was evaluated using the modified methodology of the Institute of Forest Ecosystem Research, Ltd. (IFER) (Černý et al. 2009). The following damage was classified: game barking (yes, no), mechanical damage of stem (yes, no) and stem breaks caused by abiotic factors (no damage; top crown break - in the top third of the crown; crown break - in the other two thirds of the crown; stem break - below the live crown). Except the tree layer, natural regeneration (density, species, height) and herb cover (\%) were inventoried in accordance with the Forest Management Institute practice (ÚHÚL 2003). 


\subsection{Data analysis}

Growth parameters, production, biodiversity, horizontal and vertical structure were evaluated for all individuals in the tree layer on the PRPs. Tree volume was estimated by using volume equations published by Petráš \& Pajtík (1991). Stand density index (SDI) and crown closure (CC) were calculated by Reineke (1933), respectively Crookston \& Stage (1999). Height curves were constructed using Näslund height-diameter function (Näslund 1936) in R software (C R Core Team).

To evaluate various aspects of biodiversity, the following diversity indices were computed by Sibyla 10 software (C Fabrika \& Pretzsch): species heterogeneity index (Shannon 1948), species evenness index (Pielou 1975), species richness index (Margalef 1958), Artenprofile index (Pretzsch 2006), index of diameter and height differentiation (Füldner 1995), and total stand diversity index (Jaehne \& Dohrenbusch 1997). In the Table 2 are described the criteria of structure, species and complex diversity indices.

To evaluate the spatial pattern of the stands aggregation index (Clark \& Evans 1954), index of non-randomness (Mountford 1961) and $L$-function (Ripley 1981) were calculated. The PointPro 2 program (C) Zahradnik $\&$ Pus) was used to compute the characteristics that describe the horizontal distribution of individuals across a plot. The test of significance of deviations from the values expected for the random point pattern was performed by means of Monte Carlo simulations. The mean values were estimated as arithmetic means computed for 999 randomly generated point structures.

Statistical analyses were processed in the Statistica 12 software (C) StatSoft, Tulsa). Data were log-transformed to acquire normal distribution (tested by Shapiro-Wilk test). Differences in production parameters between the types of forest origin were separately tested by one-way analysis of variance (ANOVA). A principal component analysis (PCA) was carried out in CANOCO 5 software (C) Leps \& Smilauer) to assess the relation among the stand characteristics, biodiversity and type of forest origin. Data were centred and standardized before the analysis. The results from PCA were visualized in the form of an ordination diagram. Tree damage and production quality by type of forest origin was statistically evaluated using the method of multiple comparison of $P$ parameters of binomial distribution (Anděl 1998). Variances are shown by standard deviation (SD).

\section{Results}

\subsection{Growth parameters, stand production and quality}

The density ranged between $933-3267$ trees ha ${ }^{-1}$, both in spontaneous-succession stands, and the stand density indexwas $0.89-0.99$ (Table 3). Tree density on afforested plots was relatively balanced $\left(1733-2600\right.$ trees ha- $\left.{ }^{-1}\right)$. The total mean stand volume on succession plots was $51 \mathrm{~m}^{3} \mathrm{ha}^{-1}( \pm 25 \mathrm{SD})$, and $76 \mathrm{~m}^{3} \mathrm{ha}^{-1}( \pm 20 \mathrm{SD})$ on afforested plots. The highest stand volume on succession plots $\left(78 \mathrm{~m}^{3} \mathrm{ha}^{-1}\right)$ was on PRP $6 \mathrm{~S}$ with dominant European aspen (Populus tremula L.; 61.5\%) and the lowest $\left(28 \mathrm{~m}^{3} \mathrm{ha}^{-1}\right.$ ) on PRP $5 \mathrm{~S}$ with prevailing goat willow (Salix caprea L.; 96.4\%). The highest stand volume on afforested plots $\left(97 \mathrm{~m}^{3} \mathrm{ha}^{-1}\right)$ was found on PRP 3A with $100 \%$ silver birch (Betula pendula Roth) composition and the lowest $\left(57 \mathrm{~m}^{3} \mathrm{ha}^{-1}\right)$ on PRP 2 A with prevailing black alder (Alnus glutinosa [L.] Gaertn; 60.3\%). On PRP 1A stand was formed mainly by pedunculate oak (Quercus robur L.; 71.6\%) and on PRP 4S silver birch was dominant tree species (91.5\%). Among other admixed tree species occurring on PRPs there was European ash (Fraxinus excelsior L.) and small-leaved lime (Tilia cordata Mill.).

Mean annual increment of stands currently fluctuated in the range of 0.62 (PRP 5S) - 2.13 (PRP3A) $\mathrm{m}^{3} \mathrm{ha}^{-1} \mathrm{y}^{-1}$. The total stand basal area ranged between 10.4 and $19.7 \mathrm{~m}^{2} \mathrm{ha}^{-1}$ on succession plots and $16.2-22.3 \mathrm{~m}^{2} \mathrm{ha}^{-1}$ on afforested plots (Table 3 ). Crown closure was in the range of $0.25-0.66$ and showed higher variability on succession plots, such as in other growth parameters. A comparison of the growth parameters on afforested PRPs and succession PRPs showed that the mean DBH was significantly higher on afforested plots $(9.9 \mathrm{~cm})$ than on succession PRPs $(8.1 \mathrm{~cm} ; \mathrm{P}<0.05)$, such as tree volume $\left(\mathrm{A}-0.034 \mathrm{~m}^{3}, \mathrm{~S}-0.027 \mathrm{~m}^{3} ; \mathrm{P}<0.05\right)$, while the mean height $(\mathrm{A}-10.2 \mathrm{~m}, \mathrm{~S}-9.5 \mathrm{~m})$ was similar $(\mathrm{P}>0.05)$.

The diameter distribution clearly shows another difference between the particular types of origin (Fig. 2). In the succession stands the mean number of trees was relatively balanced in the first three small-diameter classes where on PRP 2A the highest number of trees was in the second diameter class $(8-12 \mathrm{~cm})$. Strong left-sided shape of diameter classes with a typical selection structure and the highest density of trees in the first diameter of $4-8 \mathrm{~cm}$ was typical of succession plots. On these plots, we observed diameter classes of range

Table 2. Overview of indices describing the stand diversity and their common interpretation.

\begin{tabular}{|c|c|c|c|c|}
\hline Criterion & Quantifiers & Label & Reference & Evaluation \\
\hline \multirow[t]{3}{*}{ Species diversity } & Heterogeneity & $H^{\prime}$ (Shi) & Shannon (1948) & minimum $H^{\prime}=0$, higher $H^{\prime}=$ higher values \\
\hline & Evenness & $E(\mathrm{Pii})$ & Pielou (1975) & range $0-1 ;$ minimum $E=0$, maximum $E=1$ \\
\hline & Richness & $D$ (Mai) & Margalef (1958) & minimum $D=0$, higher $D=$ higher values \\
\hline \multirow[t]{2}{*}{ Horizontal structure } & Aggregation index & $R(\mathrm{C} \& \mathrm{Ei})$ & Clark \& Evans (1954) & mean value $R=1$; aggregation $R<1$; regularity $R>1$ \\
\hline & Index of non-randomness & $\alpha(\mathrm{Pi} \& \mathrm{Mi})$ & Mountford (1961) & mean value $\alpha=1$; aggregation $\alpha>1$; regularity $\alpha<1$ \\
\hline \multirow{2}{*}{$\begin{array}{l}\text { Vertical diversity } \\
\text { Structure differentiation }\end{array}$} & Arten-profile index & $A($ Pri $)$ & Pretzsch (2006) & range $0-1$; balanced vertical structure $A<0.3$; selection forest $A>0.9$ \\
\hline & $\begin{array}{l}\text { Diameter diff. } \\
\text { Height diff. }\end{array}$ & $\begin{array}{l}T M_{d}(\mathrm{Fi}) \\
T M_{b}(\mathrm{Fi})\end{array}$ & Füldner (1995) & range $0-1$; low $T M_{d}<0.3$; very high differentiation $T M_{d}>0.7$ \\
\hline Complex diversity & Stand diversity & $B(J \& \mathrm{Di})$ & Jaehne \& Dohrenbusch (1997) & $\begin{array}{l}\text { monotonous structure } B<4 \text {; uneven structure } B=6-8 \text {; very diverse } \\
\text { structure } B>9\end{array}$ \\
\hline
\end{tabular}


Table 3. Basic stand characteristics of permanent research plots $1-6$.

\begin{tabular}{|c|c|c|c|c|c|c|c|c|c|c|c|c|}
\hline PRP & $\begin{array}{c}\mathrm{t} \\
{[\mathrm{y}]}\end{array}$ & $\begin{array}{l}\mathrm{dbh} \\
{[\mathrm{cm}]}\end{array}$ & $\begin{array}{c}\mathrm{h} \\
{[\mathrm{m}]}\end{array}$ & f & $\begin{array}{c}\mathrm{v} \\
{\left[\mathrm{m}^{3}\right]}\end{array}$ & $\begin{array}{c}\mathrm{N} \\
\left.\text { [trees ha }{ }^{-1}\right]\end{array}$ & $\begin{array}{c}\mathrm{G} \\
{\left[\mathrm{m}^{2} \mathrm{ha}^{-1}\right]}\end{array}$ & $\begin{array}{c}\mathrm{V} \\
{\left[\mathrm{m}^{3} \mathrm{ha}^{-1}\right]}\end{array}$ & HDR & $\begin{array}{c}\text { MAI } \\
{\left[\mathrm{m}^{3} \mathrm{ha}^{-1} \mathrm{y}^{-1}\right]}\end{array}$ & $\mathrm{CC}$ & SDI \\
\hline $1 \mathrm{~A}$ & 45 & 10.5 & 7.90 & 0.414 & 0.028 & 2600 & 22.3 & 74 & 75.2 & 1.64 & 0.66 & 0.96 \\
\hline $2 \mathrm{~A}$ & 45 & 10.9 & 9.30 & 0.382 & 0.033 & 1733 & 16.2 & 57 & 85.3 & 1.27 & 0.44 & 0.98 \\
\hline $3 \mathrm{~A}$ & 45 & 10.8 & 14.46 & 0.377 & 0.050 & 1933 & 17.7 & 97 & 133.9 & 2.13 & 0.48 & 0.96 \\
\hline $4 S$ & 45 & 9.9 & 11.27 & 0.311 & 0.027 & 1733 & 13.3 & 47 & 113.8 & 1.04 & 0.37 & 0.95 \\
\hline $5 S$ & 45 & 12.1 & 8.54 & 0.310 & 0.030 & 933 & 10.4 & 28 & 70.6 & 0.62 & 0.25 & 0.89 \\
\hline $6 \mathrm{~S}$ & 45 & 8.8 & 8.95 & 0.441 & 0.024 & 3267 & 19.7 & 78 & 101.7 & 1.73 & 0.57 & 0.99 \\
\hline
\end{tabular}

Notes: $\mathrm{t}$ - average stand age, dbh-mean quadratic breast height diameter, $\mathrm{h}$ - mean height, $\mathrm{f}$ - form factor, $\mathrm{v}$ - mean tree volume, $\mathrm{N}$ - number of trees, $\mathrm{G}$ - basal area, $\mathrm{V}$ - stand volume, $\mathrm{HDR}$ - height to diameter ratio, MAI - mean annual increment, CC - canopy closure, SDI - stand density index.
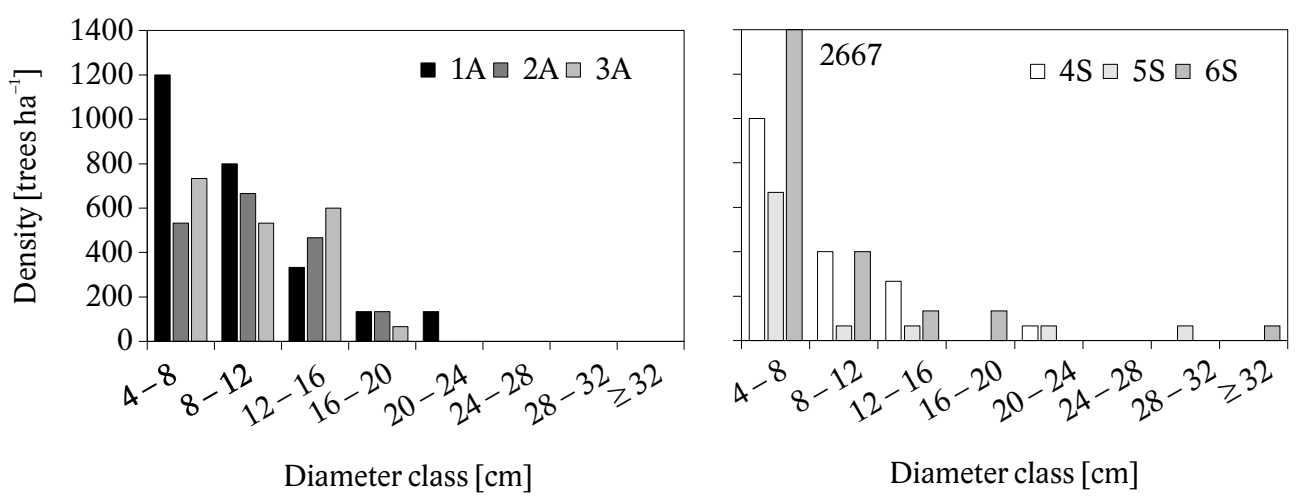

Fig. 2. Histogram of the diameter classes of the tree layer of afforested (left) and spontaneous-succession (right) stands on permanent research plots $1-6$.

$28-36 \mathrm{~cm}$, while on afforested plots no trees exceeded $\mathrm{DBH} \geq 24 \mathrm{~cm}$. On the succession PRPs the aspen tree reached the greatest diameter $(34.1 \mathrm{~cm})$, followed by a willow tree $(28.3 \mathrm{~m})$. Contrary alder on afforested PRP reached maximum DBH of only $16.2 \mathrm{~cm}$ at the same age of 45 year. Maximum DBH of oak and birch were similar $(22.1 \mathrm{~cm}$, resp. $21.1 \mathrm{~cm})$.

The tallest on the afforested PRPs was a birch $(21.1 \mathrm{~m})$, followed by an ash tree $(15.2 \mathrm{~m})$. Similarly, the maximum height on succession PRPs for aspen was $22.3 \mathrm{~m}$, and $16.1 \mathrm{~m}$ for birch. The height of the crown base of trees varied considerably, especially on succession PRPs. From aspect of relation of diameter at breast height to tree height, considerable stand differentiation with regard to stand origin and prevailing tree species was observed on PRPs (Fig. 3). The highest coefficient

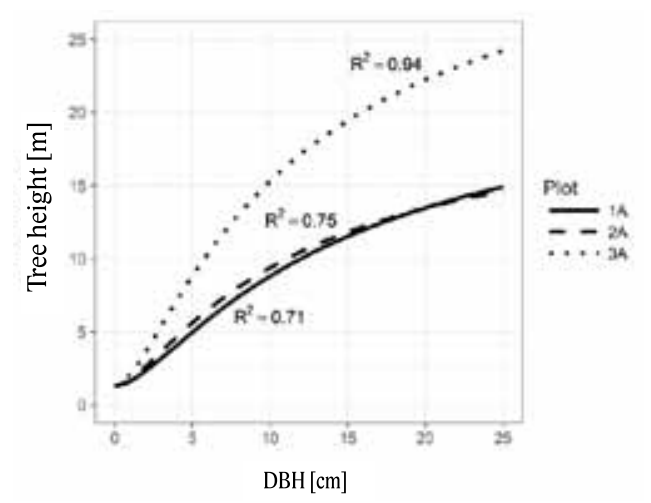

of determination $\left(\mathrm{R}^{2}\right)$ was found on the afforested birch PRP 3A, while the highest height variability was on the succession poplar and willow PRP 6S, respectively 5S. HDR decreases with DBH while a more pronounced decrease, with the higher variability in afforested trees, was observed in the thinnest trees when the variance of values was maximum.

In terms of production quality, occurrence of all the types of breaks (top, crown, stem) was significantly $(\mathrm{P}<0.05)$ higher on afforested PRPs $(15 \%)$ compared to succession PRPs (7\%). The largest break damage was found in afforested PRP 2A with dominant alder (22\%) compared to the smallest occurrence of breaks on succession PRP 4S with birch (4\%). Tree vitality and crown quality did not show significant differences $(P>0.05)$. The average tree vitality on the afforested PRPs reached

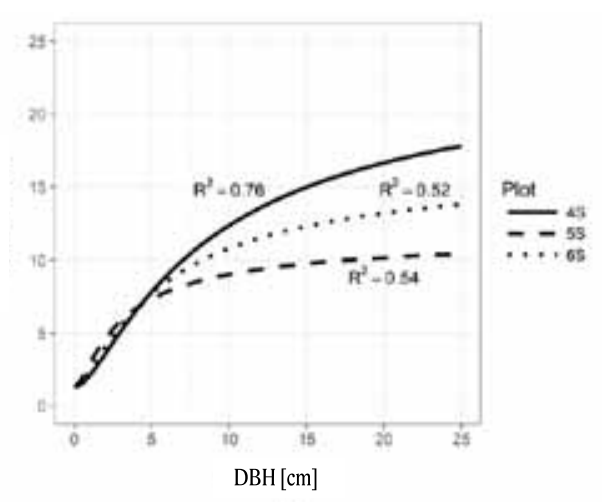

Fig. 3. The relationship between DBH and tree height of the tree layer of afforested (left; parameter $a 0.98-1.57, b 0.17-0.22$ ) and spontaneous-succession (right; $a 0.64-0.95, b 0.21-0.29$ ) stands on permanent research plots $1-6$ with coefficient of determination $\left(\mathrm{R}^{2}\right)$. 
$64 \%$, respectively the average crown quality was $50 \%$, similarly such as on the succession PRPs (values 61\% and $44 \%$ ). Conversely, stem quality was significantly ( $P$ $<0.05$ ) higher on afforested PRPs (the best quality with straight stem $-28 \%$, the worst quality with large curved stem - 22\%) compared to succession PRPs (the best quality $-21 \%$, the worst quality $-40 \%$ ).

\subsection{Biodiversity and structure of tree layer}

Species richness ranged from low diversity $(D=0.000-$ 0.134 ) on afforested PRPs to medium diversity $(D=0.268$ -0.371) on succession PRPs (Table 4). Similarly, species heterogeneity was at a low level $\left(H^{\prime}=0.000-0.265\right)$ on afforested PRPs compared to a high level on succession PRP 6S $\left(H^{\prime}=0.532\right)$. Species evenness ranged from none to very high $(E=0.000-0.884)$ diversity, again reaching its maximum on RPP6S. The vertical structure according to $A$ index was moderately to strongly-varied ( $A=0.447$ $-0.744)$. Diameter differentiation was low to medium $\left(T M_{d}=0.112-0.315\right)$, but height differentiation was only at a low level $\left(T M_{h}=0.108-0.261\right)$. A generally higher structural diversity was observed in afforested stands. Total stand diversity $B$ suggested a prevailing even structure on PRPs $(B=4.689-5.704)$ except for a more diverse structure on PRP $6 \mathrm{~S}(B=8.183)$.

The horizontal structure was regular on afforested PRPs, while the spatial pattern on succession PRPs was significantly $(\mathrm{P}<0.05)$ aggregated (Table 4, Fig. 4). The exception was PRP 2A and 6S, where, according to the $R$ and $\alpha$ index, the distribution of tree layer individuals was random. On afforested birch PRPs (3A) there was a mostly regular distribution of tree layer individuals, while the most aggregated spatial pattern was found on a willow succession plot (5S) with the lowest tree density. According to the tree distance as follows from Ripley's $L$-function, on PRP $1 \mathrm{~A}$ and $3 \mathrm{~A}$ the spatial pattern was aggregated at a distance shorter than $1.5 \mathrm{~m}$. On the other hand, the regular spatial pattern of the tree layer occurred at $1-2 \mathrm{~m}$ distances on PRP $4 \mathrm{~S}$ and more than $2.5 \mathrm{~m}$ on PRP 5S. On PRP 2A and 6S, $L$-function also confirmed a random horizontal structure (Fig. 4).

Table 4. Indices of the tree layer biodiversity on permanent research plots $1-6$.

\begin{tabular}{lccccccccc}
\hline PRP & $D(\mathrm{Mai})$ & $H^{\prime}(\mathrm{Si})$ & $E(\mathrm{Pii})$ & $R(\mathrm{C} \& \mathrm{Ei})^{*}$ & $\alpha(\mathrm{P} \& \mathrm{Mi})^{*}$ & $A(\mathrm{Pri})$ & $T M_{d}(\mathrm{Fi})$ & $T M_{b}(\mathrm{Fi})$ & $B(\mathrm{~J} \& \mathrm{Di})$ \\
\hline 1A & 0.127 & 0.227 & 0.754 & 1.200 & $0.804^{\mathrm{R}}$ & 0.649 & 0.304 & 0.256 & 5.473 \\
2A & 0.134 & 0.265 & 0.880 & 1.112 & 1.040 & 0.631 & 0.227 & 0.171 \\
3A & 0.000 & 0.000 & 0.000 & $1.469^{\mathrm{R}}$ & $0.712^{\mathrm{R}}$ & 0.744 & 0.315 & 0.261 \\
4S & 0.268 & 0.250 & 0.524 & $0.774^{\mathrm{A}}$ & 1.300 & 0.560 & 0.219 & 0.196 \\
5S & 0.292 & 0.224 & 0.469 & $0.606^{\mathrm{A}}$ & $4.335^{\mathrm{A}}$ & 0.447 & 0.112 & 0.108 \\
6S & 0.371 & 0.532 & 0.884 & 1.071 & 1.061 & 0.706 & 0.253 & 0.207 \\
\hline
\end{tabular}

Notes: $D$ - species richness index, $H^{\prime}$ - species heterogeneity index (entropy), $E$ - species evenness index, $\alpha$-index of non-randomness, $R$ - aggregation index, $A$-Arten-profile index, $T M_{d}-$ diameter differentiation index, $T M_{h}$ - height differentiation index, $B$ - total diversity index; * statistically significant ${ }^{\mathrm{A}, \mathrm{R}}(\mathrm{P}<0.05 ; \mathrm{A}$ - aggregation, $\mathrm{R}$-regularity).

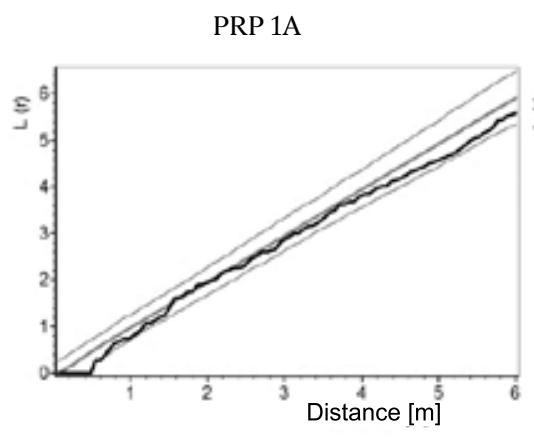

PRP 4S

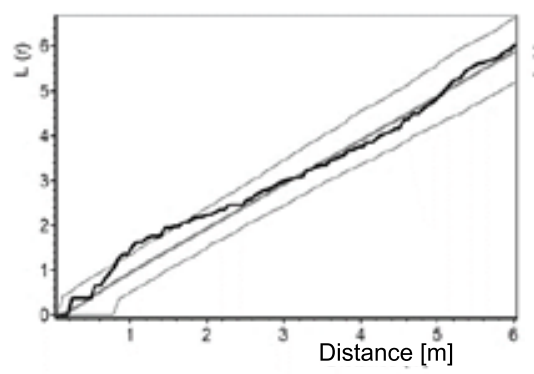

PRP 2A

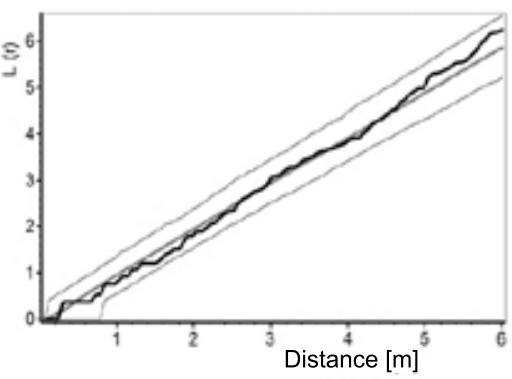

PRP 5S

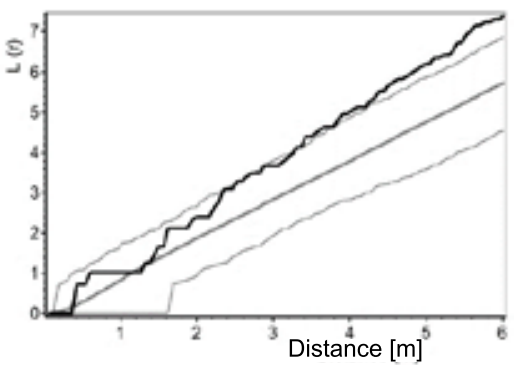

PRP 3A

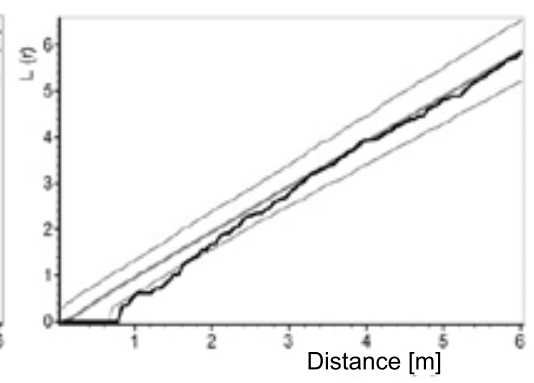

PRP 6S

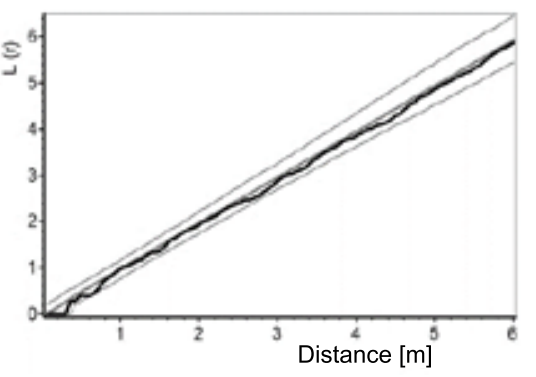

Fig. 4. Horizontal structure of the tree layer on permanent research plots $1-6$ expressed by $L$-function; the bold grey line represents the mean course for random spatial distribution of trees and the two thinner central curves represent the $95 \%$ interval of reliability; when the bold black line of tree distribution on the plot drops below this interval, it indicates a tendency of trees toward regular distribution; if above this interval, they tend toward aggregation. 


\subsection{Relationships among stand characteristics, biodiversity and type of forest origin}

The results of PCA are depicted by an ordination diagram in Fig. 5. The first ordination axis explains $54.9 \%$, the first two axes $84.6 \%$ and first four axes the total of $98.5 \%$ of data variability. The $\mathrm{x}$-axis represents the stand volume, Arten-profile index and diameter differentiation. The $y$-axis represents complex diversity and species evenness and heterogeneity. Canopy closure is positively correlated with the number of trees and stocking, while these parameters are negatively correlated with the mean DBH. All study structural indices representing vertical and horizontal structure, diameter and height differentiation have positive relationship with the stand volume. The species diversity (evenness, richness, heterogeneity) is positively correlated with the total stand diversity, while these parameters are negatively correlated with the height and also with HDR, but its contribution is relatively small.

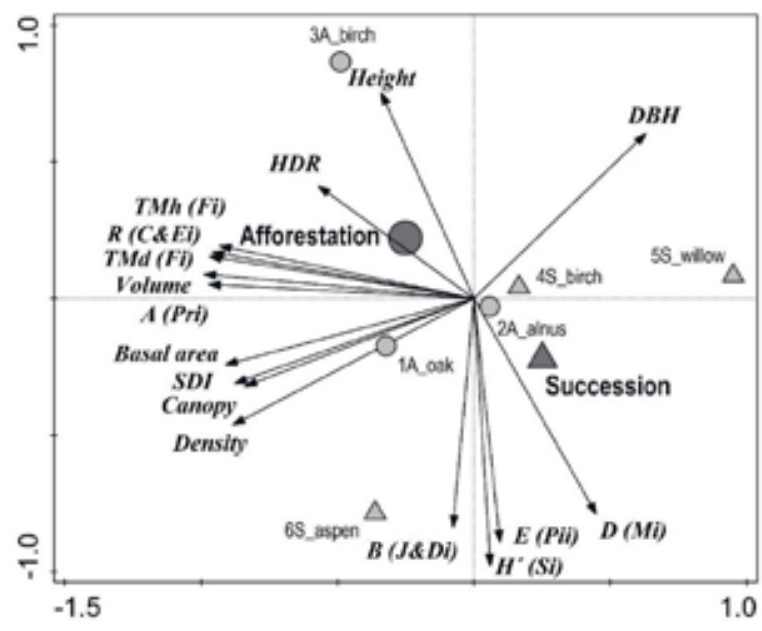

Fig. 5. Ordination diagram showing results of the PCA analysis of relationships between stand characteristics (Volume, Basal area, DBH - diameter at breast height, Height, Canopy - canopy closure, Density - number of trees, HDR - slenderness ratio, SDI - stand density index/stocking), structural diversity ( $A$ - Arten-profile index, $T M d$ - diameter differentiation, $T M h$ - diameter differentiation, $R$ - aggregation index), species diversity ( $E$ - evenness, $D$ - richness, $H^{\prime}$ - heterogeneity), complex diversity ( $B$ index) and type of stand origin ( $\bullet$ afforestation/planted, $\boldsymbol{\Delta}$ succession/left to self-development); Codes indicate plots with the type of origin and prevailing tree species.

The type of stand origin shows a low effect on mutual relationships among production parameters compared to great differences among diversity indices. The diagram also shows large differences among plots due to predominant tree species. Differences of types of origin are remarkable especially for the spontaneous-succession stand as marks of each record are relatively distant from one another whereas marks for planted stands are close together in the diagram. Plots with different type of origin are different from one another - the succession plots with high species and complex diversity occupy the right down part of the diagram, while the high stand volume and regular spatial pattern were typical for artificially afforested stands.

\section{Discussion}

In the examined area of Antonín-Sokolov reclamation site the number of trees on average reached 1978 trees ha ${ }^{-1}$ on succession plots with the stand volume of $51 \mathrm{~m}^{3} \mathrm{ha}^{-1}$, while the density on afforested plots was on average 2089 trees $\mathrm{ha}^{-1}$ and the stand volume ranged about $76 \mathrm{~m}^{3} \mathrm{ha}^{-1}$ at age of 45 years. The highest stand volume was measured on the plot afforested by silver birch. Comparison of basic stand characteristics on afforested reclamation sites in Europe is complicated because of the lack of data for particular tree species. Reclamation sites were mostly afforested with Scots pine (Pinus sylvestris L.) (Heinsdorf 1996; Katzur \& Haubold-Rosar 1996; Knoche 2005; Bacia \& Barzdajn 2007; Pietrzykowski 2014; Likus-Cieślik \& Pietrzykowski 2017), for example there were 780 trees ha $^{-1}$ in a 66 years old pine forest and the total stand volume was $330 \mathrm{~m}^{3} \mathrm{ha}^{-1}$ (Knoche 2005), but this stand's characteristics are given for different age and tree species. Comparing to studied tree species, the stand volume on succession plots in reclaimed open-cast mining areas in Estonia show a significantly higher value (3-5 times) only at the age of 30 years. The stand volume of alder plots was $280 \mathrm{~m}^{3} \mathrm{ha}^{-1}$ and even $340 \mathrm{~m}^{3} \mathrm{ha}^{-1}$ in birch stands (Pensa et al. 2004). The study from reclaimed mining sites (Kuznetsova et al. 2011) also confirmed a high production potential of alder stands compared to other tree species, but in our study the alder stand reached the lowest production from all afforested plots. In Poland, stand productivity of the English oak in the conditions of a reclaimed external dump of Piaseczno sulphur mine ranged between $103-176 \mathrm{~m}^{3} \mathrm{ha}^{-1}$ with tree density of 846 trees ha $^{-1}$ at age of 40 years (Pietrzykowski et al. 2015), but in our study at similar age oak volume reached only $74 \mathrm{~m}^{3}$ ha ${ }^{-1}$ with density of 2400 trees ha ${ }^{-1}$. Similar stand volume was observed in same country from external spoil bank of the Bełchatów brown coal mine $\left(66 \mathrm{~m}^{3} \mathrm{ha}^{-1}\right)$ only at the age of 20 years, where black poplar (Populus nigra L.) and black locust (Robiniapseudoacacia L.) were characterized by the best productivity compared to lowest volume in black alder (Pająk et al. 2004), such as in our study.

Compared with the overall condition of birch stands in the Czech Republic, the birch succession plots near the thermal power plant in Poříčí (near Trutnov, northeast Bohemia) showed significantly higher production quantities and slightly higher production quality, both in forest stands (Fagetum acidophilum) and reclaimed spoil heaps 
(Fagetum lapidosum acidophilum). The stand volume per hectare ranged from $198-238 \mathrm{~m}^{3}$ in 35 -year-old stands (Vacek et al. 1987; Vacek 1991). A higher stand volume of $113-147 \mathrm{~m}^{3} \mathrm{ha}^{-1}$ was also found on birch and alder (45 years) succession plots created on degraded soils of an air shooting range in eastern Bohemia (Vacek et al. 2009). When compared to similar age groups (4753 years) on former agricultural land in the Orlické hory Mts., the stand volume of birch succession stands ranged from $244-309 \mathrm{~m}^{3} \mathrm{ha}^{-1}$, and in artificially established alder stands it even reached $354 \mathrm{~m}^{3} \mathrm{ha}^{-1}$ (Vacek et al. 2009, 2016). Comparable production was found only at reclaimed Jirásek and Breňany localities in west Bohemia, where ash and birch stands reached $75-106 \mathrm{~m}^{3} \mathrm{ha}^{-1}$ (Vacek et al. 2009) but the average age of the stand was 20 years less than in the studied Antonín-Sokolov locality. Ones of the main reasons for the low production of the stand on the studied site is caused, among other reasons, mainly by unfavorable soil conditions and insufficient silvicultural interventions

The diameter distribution shows also different trends: on succession plots, the highest frequency was found in the first diameter class $(4-8 \mathrm{~cm})$ with a strong decline in the following classes, while approximately balanced numbers of trees in first three diameter classes was observed on afforested plots (Vacek et al. 2009). Quality of production is also related to the origin of forest stands. Stem quality was significantly higher in the artificially afforested stands where the best quality with straight stems reached $28 \%$ of stems and the worst quality was found in $22 \%$ stems, while on the succession plots was the best quality found in $21 \%$ and the worst quality in $40 \%$.

Evaluation of biodiversity and structure of tree layer also show important characteristics of stands. Tree species richness ranged from low diversity $(D=0.00-0.13)$ on afforested PRPs to medium diversity $(D=0.27-0.37)$ on succession PRPs. Similarly, on Estonian spoil heaps, the species diversity was the largest in the succession areas and the smallest in the birch plantation (Pensa et al. 2004). In the Antonín-Sokolov spoil heap, aggregated distribution prevailed on the successive areas, and random and regular distribution in the artificially afforested stands, in the similar way as on former agricultural lands in the Orlické hory Mts. (Vacek et al. 2009). A comparison of the spoil heap and the forest land in Trutnov brought similar results (Vacek 1991). The succession forest stands also showed a larger overall stand diversity than the afforested stands. In the Orlické hory Mts., up to twice the diversity of the succession stands with dominating alder and birch $(\mathrm{B}=8.26-10.26)$ was found in comparison with the artificially afforested stands $(B=5.97)$. This is due to the fact that the growth of these stands is temporally and spatially highly differentiated (Vacek et al. 2018). Trees that colonize postindustrial sites are, thus, natural tools that contribute to mitigating microclimatic stress, improving the quality of the substrate and purifying the air (Prausová et al. 2017). Their existence influences other organisms. Their biological activity (leaf fall and underground and above-ground biomass growth) gradually cultivates habitat and subsequently the environment (Byers et al. 2006). In the first stage of development, however, the seedlings and juveniles of pioneer tree species (Betula pendula, Populus tremola, Salix caprea etc.) are very sensitive to any kind of stress, especially summer drought, overheating and frost (Kováŕ 2004). In unfavorable situations, their mortality is high (Kovár \& Herben 2004) but decreases with the growing density of vegetation (Matějíček \& Kovář 2015). A favourable effect of the ecological cover of shrubs on the growth of trees in the juvenile stage is widely known (Gómez-Aparicio 2009; Rejzek et al. 2016). The extreme environment thus has a great influence on the biodiversity of the succession stands on immature soils (Prausová et al. 2017).

It is important is to reflect the aim of reclamation by afforestation. Forest stands production plays only a minor role in this case and the timber quantity and quality cannot compete with standard forest stands. Future management of forest stands, growing on these poor spoil heap sites, is another issue to be addressed. One of the possibilities is to improve the stand conditions by fertilizers, which were already tested on reclamation sites, e.g. dolomite fertilization (Bacia \& Barzdajn 2007) or brown coal ash (Katzur \& Haubold-Rosar 1996). It is also possible to use fertilizers tested on standard forest stands (Podrázský et al. 2003; Ferreiro-Domínguez et al. 2011; Cukor et al. 2017a, b). Successful amelioration requires exploration of soil conditions that identify limiting soil parameters on reclamation sites (Katzur \& HauboldRosar 1996). Another alternative is to reduce the basal area of pioneer tree species by strong thinning and, subsequently, to underplant them with hardwood trees as Fagus sylvatica (L.) or Quercus spp. (Knoche 2005). All the discussed forest stands parameters are interesting from the future point of view, because afforestation is still one of the cheapest solution of reclamation (Kubát 2008) assumed to be used further ahead.

\section{Conclusion}

Afforested stands in Antonín spoil heaps in the Sokolov vicinity show a higher stand volume and quality production compared to forest stands originated by natural succession. However, non-homogenous conditions and small number of the compared plots, due to the inception of this long-term research, must be considered when interpreting the present results. Timber production and economic benefit do not constitute the primary function of afforested reclamations; forest stands have positive effect on the soil and microclimatic conditions and offer other non-market functions, e.g. ecological, social, aesthetical etc. The Antonín-Sokolov Forestry Arboretum is therefore very important as it represents a sole recreational and suburban educational forest in the area, which was strongly affected by coal mining in the surroundings of the Sokolov town. From the scientific point of view, 
Antonín-Sokolov is a unique place with more than 220 species and cultivars of original and introduced tree species and their growth in specific conditions brings unique results. For the above-mentioned reasons, the spoil heap afforestation and its development will raise a number of new questions and encourage further research in the future.

\section{Acknowledgement}

This study was supported by the Czech University of Life Sciences Prague, Faculty of Forestry and Wood Sciences (No. IGA A16/17). Data were obtained by the project GS LC $\check{C}$ "Utilization of the multifunctional potential of the reclamation AntonínSokolov Forestry Arboretum" (No. 13/2016). We thank two anonymous reviewers for their constructive comments and suggestions that helped improve the manuscript.

\section{References}

Anděl, J., 1998: Statistické metody. Matfyzpress, Praha, $274 \mathrm{p}$.

Bacia, J., Barzdajn, W., 2007: Effects of soil reclamation on afforestation of degraded areas in the Chocianow Forests District. Sylwan, 151:44-51.

Brandi, C., 2015: Safeguarding the earth system as a priority for sustainable development and global ethics: the need for an earth system SDG. Journal of Global Ethics, 11:32-36.

Buček, A., Lacina, J., 2001: Harmonická kulturní krajina venkova - sny a realita. In: Tvář naší země - krajina domova. Sborník př́spěvků z konference z 21. - 23. února 2001 na Pražském hradě a v Průhonicích. Praha, Česká komora architektů, p. 71-76.

Byers, J. E., Cuddington, K., Jones, C. G., Talley, T. S., Hastings, A., Lambrinos, J. G. et al., 2006: Using ecosystem engineers to restore ecological systems. Trends in Ecology \& Evolution, 21:493-500.

Clark, P.J., Evans, F. C., 1954: Distance to nearest neighbour as a measure of spatial relationship in populations. Ecology, 35:445-453.

Cukor, J., Linhart, L., Vacek, Z., Baláš, M., Linda, R., 2017:The Effects of Alginite Fertilization on Selected Tree Species Seedlings Performance on Afforested Agricultural Lands. Central European Forestry Journal, 63:48-56.

Cukor, J., Vacek, Z., Linda, R., Remeš, J., Bílek, L., Sharma, R. P. et al., 2017: Effect of mineral eco-fertilizer on growth and mortality of young afforestations. Austrian Journal of Forest Science, 134:367-386.

Černý, M., Cienciala, E., Russ, R., 2009: Metodika terénního šetření v systému inventarizace krajiny CzechTerra. IFER - Ústav pro výzkum lesních ekosystémů, s.r.o., Czech Republic, 70 p.

Dimitrovský, K., 2001: Tvorba nové krajiny na Sokolovsku. Sokolov, Sokolovská uhelná, 191 p.
Dimitrovský, K., Kunt, M., Vacek, O., 2016: Geneze antropogenních substrátů na výsypkách jako základ pro vytvoření lesnické rekultivační typologie. Zpravodaj Hnědé uhlí, 1:39-51.

Dimitrovský, K., Kupka, I., Popperl, I., 2007: Les jako důležitý fenomén obnovy průmyslové krajiny. In: Obnova lesního prostředí při zalesňování zemědělských a degradovaných půd. Kostelec nad Černými lesy, 22. 11. 2007, ČZU v Praze, p. 20-27.

Dimitrovský, K., Modrá, B., Prokopová, D., 2010: Produkční a mimoprodukční význam antropogenních substrátů na výsypkách sokolovské uhelné pánve. Zpravodaj Hnědé uhlí, 4:8-16.

Ellis, E. C., Ramankutty, N., 2008: Putting people in the map: anthropogenic biomes of the world. Frontiers in Ecology and Environment, 6:439-447.

Erisman, J. W., Galloway, J. N., Seitzinger, S., Bleeker, A., Dise, N. B., Roxana Petrescu, A. M. et al., 2013: Consequences of human modification of the global nitrogen cycle. Philosophical Transactions of the Royal Society B 368: 20130116.

Ferreiro-Domínguez, N., Rigueiro-Dodríguez, A., Mosquera-Losada, M. R., 2011: Response to sewage sludge fertilisation in a Quercus rubra L. silvopastornal system: Soil, plant biodiversity and tree and pasture production. Agriculture, Ecosystems and Environment, 141:9-57.

Feudean, A., Munteanu, C., Kuemmerle, T., Nielsen, A. B., Hutchinson, S. M., Ruprecht, E. et al., 2017: Long-term land-cover/use change in a traditional farming landscape in Romania inferred from pollen data, historical maps and satellite images. Regional Environmental Change, 8:2193-2207.

Füldner, K., 1995: Strukturbeschreibung von Buchen-Edellaubholz-Mischwäldern. Dissertation Forstliche Fakultät Göttingen, Cuvillier Verlag, Göttingen, Germany, $146 \mathrm{p}$.

Glos, R., 2016: Pojetí výchovných zásahů v porostech introdukovaných dřevin na výsypce Antonín na Sokolovsku. Diplomová práce, FLD ČZU v Praze, 64 p.

Gómez-Aparicio, L., 2009: The role of plant interactions in the restoration of degraded ecosystems: a metaanalysis across life-forms and ecosystems. Journal of Ecology, 97:1202-1214.

Graf, F., Frei, M., 2013: Soil aggregate stability related to soil density, root length, and mycorrhiza using sitespecific Alnus incana and Melanogaster variegatus s.l. Ecological Engineering, 57:314-323.

Hastings, A., Byers, J. E., Crooks, J. A., Cuddington, K., Jones, C. G., Lambrinos, J. G. et al., 2007: Ecosystem engineering in space and time. Ecology Letters, 10:153-164.

Heinsdorf, D., 1996: Development of forest stands in the Lusatian lignite mining district after mineral rertilization adapted to site and tree species. Water, Air, and Soil Pollution, 91:33-42. 
Hendrychová, M., Kabrna, M., 2016: An analysis of 200-year-long changes in a landscape affected by large-scale surface coal mining: History, present and future. Applied Geography, 74:151-159.

Hilson, G., 2002: An overview of land use conflicts in mining communities. Land Use Policy, 19:65-73.

Jaehne, S., Dohrenbusch, A., 1997: A method to evaluate forest stand diversity. Forstwissenshaftliches Centralblatt, 116:333-345.

Katzur, F., Haubold-Rosar, M., 1996: Amelioration and reforestation of sulfurous mine soils in Lusatia (Eastern Germany). Water, Air, and Soil Pollution, 91:17-32.

Knoche,D., 2005: Effects of stand conversion by thinning and underplanting on water and element fluxes of a pine ecosystem (P. sylvestris L.) on lignite mine spoil. Forest Ecology and Management, 212:214-220.

Kovář, P., 2004: Industrial deposits of abandoned sedimentation basins - technology of the origin and vegetation. In: Kovář, P., (ed.): Natural Recovery of Human-Made Deposits in Landscape (Biotic Interactions and Ore/Ash-Slag Artificial Ecosystems), Academia, Prague, p. 15-29.

Kovář, P., Herben, T., 2004: Small-scale spatiotemporal dynamics of plant cover during the initial phase of primary succession in an abandoned ore-washery sedimentation basin. In: Kovář, P., (ed.): Natural Recovery of Human-Made Deposits in Landscape (Biotic Interactions and Ore/Ash-Slag Artificial Ecosystems), Academia, Prague, p. 277-284.

Kubát, J., 2008: History and Present Situation on Reclamation of Spoil Banks in the Sokolov Region. Scientia Agriculturae Bohemica, 39:342-347.

Kupka, I., Dimitrovský, K., 2011: Test results of selected tree species for forestry reclamations in the sokolov region: Review. Zprávy lesnického výzkumu, 56:5256.

Kuznetsova, T., Lukjanova, A., Mandre, M., Lõhmus, K., 2011: Aboveground biomass and nutrient accumulation dynamics in young black alder, silver birch and Scots pine plantations on reclaimed oil shale mining areas in Estonia. Forest Ecology and Management, 262:56-64.

Lanz, B., Dietz, S., Swanson, T., 2018:The Expansion of Modern Agriculture and Global Biodiversity Decline: An Integrated Assessment. Ecological Economics, 144:260-277.

Likus-Cieślik, J., Pietrzykowski, M., 2017: Vegetation development and nutrients supply of trees in babitats with high sulfur concentration in reclaimed former sulfur mines Jeziórko (Southern Poland). Environmental Science and Pollution Research, 24:2055620566.

Maděra, P., Kovářová, P., 2004: Primary succession of white willow communities in the supraregional biocorridor in the Middle water reservoir of Nové Mlýny. Ekológia, 23:191-204.
Matějíček, L., Kovář, P., 2015: Computer Based Modeling of Vegetation Propagation across a Disturbed Space Linked to GIS. Journal of Earth Science and Engineering, 5:410-416.

Margalef, R., 1958: Information theory in ecology. General Systematics, 3:36-71.

Mountford, M.D., 1961: On E. C. Pielou's index of nonrandomness. Journal of Ecology, 49:271-275.

Näslund, M., 1936: Skogsförsöksanstaltens gallringsförsök i tallskog. Meddelanden från Statens Skogsförsöksanstalt, Swedish Institute of Experimental Forestry, 29:169.

Pająk, M., Forgiel, M., Krzaklewski, W., 2004: Growth of trees used in reforestation of a northern slope of the external spoil bank of the "Bełchatów" Brown Coal Mine. Electronic Journal of Polish Agricultural Universities, Series Forestry, 7:\#02.

Paz-Kagan, T., Zaady, E., Shachak, M., Karnieli, A., 2016: Transformation of shrublands to forests: The role of woody species as ecosystem engineers and landscape modulators. Forest Ecology and Management, 361:257-268.

Pensa, M., Sellin, A., Luud, A., Valgma, I., 2004: An analysis of vegetation restoration on opencast oil shale mines in Estonia. Restoration Ecology, 12:200-206.

Petráš, R., Pajtík, J., 1991: Sústava česko-slovenských objemových tabuliek drevín. Lesnícky časopis, 37:49-56.

Pietrzykowski, M., 2014: Soil quality index as a tool for Scots pine (Pinus sylvestris) monoculture conversion planning on afforested, reclaimed mine land. Journal of Forestry Research, 25:63-74.

Pietrzykowski, M., Krzaklewski, W., Likus, J., Woś, B., 2015: Assessment of english oak (Quercus robur L.) growth in varied soil-substrate conditions of reclaimed Piaseczno sulfur mine dump. Folia Forestalia Polonica, 57:28-32.

Pielou, E. C., 1975: Ecological diversity. Wiley, New York, $165 \mathrm{p}$.

Podrázský, V., Remeš, J., Ulbrichová, I., 2003: Biological and chemical amelioration effects on the localities degraded by bulldozer site preparation in the Ore Mts. - Czech Republic. Journal of Forest Science, 49:141-147.

Prach, K., 1995: „Restaurační ekologie“ či ekologie obnovy? Vesmír, 74:143-144.

Prach, K., Tichý, L., Lencová, K., Adámek, M., Koutecký, T., Sádlo, J. et al., 2016: Does succession run towards potential natural vegetation? An analysis across series. Journal of Vegetation Science, 27:515-523.

Prausová, R., Štefánek, M., Rauch, O., Kovář, P., 2017: Trees as ecosystem engineers driving vegetational restoration/retrogradation of industrial deposits in cultural landscape. Journal of Landscape Ecology, 10:122-131. 
Pretzsch, H., 2007: Analysing and Modelling Forest Stand Dynamics for Practical Application - An European Review and Perspective. Eurasian Journal of Forest Science, 10:1-187.

Rebele, F., Lehmann, C., 2016: Twenty years of woodland establishment through natural succession on a sandy landfillsite in Berlin, Germany. Urban Forestry \& Urban Greening, 18:182-189.

Rejžek, M., Svátek, M., Šebesta, J., Adolt, R., Maděra, P., Matula, R., 2016. Loss of a single tree species will lead to an overal decline in plant diversity: Effect of Dracaena cinnabari Balf. F. on the vegetation of Socotra Island. Biological Conservation, 196:165172.

Sádlo, J., Tichý, L., 2002: Sanace a rekultivace po lomové a důlní těžbě. ZO ČSOP Pozemkový spolek Hády, Brno, $36 \mathrm{p}$.

Schadelin, W., 1931: Über Klasseneinteilung und Qualifikation der Waldbiiume. SchweizerischeZeitschrift für Forstwesen, 82:1-12.

Shannon, C. E., 1948: A mathematical theory of communications. Bell System Technical Journal, 27:379423.

Simon, J., Vacek, S., Buček, A., Šebesta, J., 2005: Růstová dynamika a stav lesních porostů na Dolech Bílina. Brno, LDF MZLU v Brně, 53 p.

Sklenička, P., Charvatova, E., 2003: Stand continuity - a useful parameter for ecological networks in post-mining landscapes. Ecological Engineering, 20:287-296.

Slonecker, E. T., Benger, M. J., 2001: Remote sensing and mountaintop mining. Remote Sensing Reviews, 20:293-322.

Sýkorová, Z., Rydlová, J., Slavíková, R., Ness, T., Kohout, P., Püschel, D., 2016: Forest reclamation of fly ash deposit: a field study on appraisal of mycorrhizal inoculation. Restoration Ecology, 24:184-193.

Štrupl, M., 1960: Rekultivace uhelných výsypek. In: Jeník, J. et al., 1960: Tvorba a ochrana krajiny. Praha, Nakladatelství ČSAV, p. 68-72.
Štýs, S., 2001: Proměny krajiny Severočeskéhnědouhelné pánve. Sborník př́ispěvků z konference. In:Tvář naší země - krajina domova. 21. - 23. 2. 2001, Praha, Česká komora architektů, 5:145-158.

Tittensor, D. P., Walpole, M., Hill, S. L. L., Boyce, D. G., Britten, G. L., Burgess, N.D. et al., 2014: Amid-term analysis of progress toward international biodiversity targets. Science, 346:241-244.

ÚHÚL, 2003: Inventarizace lesů. Metodika venkovního sběru dat. Brandýs nad Labem, Forest Management Institute, $136 \mathrm{p}$.

Ustaoglu, E., Williams, B., 2017: Determinants of Urban Expansion and Agricultural Land Conversion in 25 EU Countries. Environmental Management, 60:717-746.

Vacek, S., Lepš, J., Tesař, V., 1987: Skladba mladých březových porostů na Trutnovsku. Lesnictví, 33:343360.

Vacek, S., 1991: Porostotvorné schopnosti břízy a jeřábu podvlivemimisí.Zprávy lesnického výzkumu,36:1923.

Vacek, S., 1992: Struktura a vývoj mladých jeřábových a březových porostů. Opera corcontica, 29:85-121.

Vacek, S., Simon, J., Podrázský, V., Baláš, M., Slávik, M., Mikeska, M. et al., 2009: Zakládání a stabilizace lesních porostů na bývalých zemědělských a degradovaných půdách. Kostelec nad Černými lesy, Lesnická práce, $792 \mathrm{p}$.

Vacek, S., Vacek, Z., Kalousková, I., Cukor, J., Bílek, L., Moser, W. K. et al., 2018: Sycamore maple (Acer pseudoplatanus L.) stands on former agricultural land in the Sudetes - evaluation of ecological value and production potential. Dendrobiology, 79:61-76.

Vacek, Z., Vacek, S., Podrázský, V., Král, J., Bulušek, D., Putalová, T. et al., 2016: Structural diversity and production of alder stands on former agricultural land at high altitudes. Dendrobiology, 75:31-44.

WWF, 2016: Living Planet Report 2016. Risk and resilience in a new era. WWF International, Gland, Switzerland, $144 \mathrm{p}$. 